\title{
"A ebulição na massa d'água" ou a linguagem segundo Merleau-Ponty
}

Leandro Neves Cardim

lncardim@usp.br

Universidade Federal do Paraná, Curitiba, Paraná, Brasil

resumo Este trabalho investiga alguns desdobramentos das relações entre a linguagem criadora e a linguagem sedimentada na obra de Maurice Merleau-Ponty. Trata-se de avaliar as diferentes posições adotadas pelo filósofo a propósito desta relação utilizando como fio condutor a imagem do líquido em ebulição. A força heurística desta imagem nos ajudará, por um lado, a compreender os diferentes pontos de vista utilizados para interpretar o fenômeno da linguagem; por outro, servirá como índice para acompanharmos a retificação e o aprofundamento interno desta filosofia.

palavras-chave Merleau-Ponty; silêncio; linguagem; ambiguidade; circularidade; dimensão.

Para compreender as reflexões merleau-pontianas sobre a linguagem é preciso apontar desde o início duas direções de análise presentes em toda obra: em primeiro lugar, a vida da linguagem sempre passa despercebida em proveito daquilo que ela exprime. Isto acontece porque "a expressão se apaga diante do expresso, e é por isso que seu papel mediador pode passar despercebido" (MERLEAU-PONTY, 1996, p.537). Esta espécie de transparência da linguagem para quem fala revela o fato de que estamos tão imersos nela que seu papel fundamental não é notado. A fala atravessa as formas significantes da linguagem para ir direto às coisas que ela significa: uma vez que o instrumento linguístico realiza sua função, o falante esquece sua operação. Esta característica da linguagem é tão marcante que Merleau-Ponty chega a identificá-la como a "maravilha da linguagem" que consiste, precisamente, em que "ela se faz esquecer" 
(MERLEAU-PONTY, 1996, p.537). Em segundo lugar, há o papel criador da linguagem, a qual nasce no mundo sensível e se diferencia dele. Esta função criadora está estreitamente relacionada com sua própria vida,já que ao fazer-se ela "se reitera, apoia-se em si mesma ou que, assim como uma onda, ajunta-se e retoma-se para projetar-se para além de si mesma” (MERLEAU-PONTY, 1996, p.267). Merleau-Ponty nunca deixará de investigar e aprofundar a relação entre a linguagem sedimentada e a linguagem viva, de tal modo que nem a importância nem o papel de cada uma destas formas de linguagem permanecerão inalterados no decorrer de seu itinerário filosófico.

No geral, a interrogação sobre a possibilidade da linguagem é solidária de uma investigação sobre a possibilidade e o lugar da reflexão ou da filosofia. "Nascemos na razão como na linguagem", diz o Prefácio de Sentido e não sentido escrito em 1948. Assim como na linguagem em que o fundo de silêncio está sempre presente, sob o sentido haverá sempre o fundo do não sentido. Há linguagem e razão desde que seja possível uma reflexão sobre o irrefletido, ou melhor, desde que o pensamento mais abstrato esteja imerso no mundo: a verdade do pensamento deriva do fato de que a existência pré-reflexiva sustenta e carrega toda abstração. A linguagem mais abstrata reenvia ao mundo sensível, ela está radicada nele e justamente por isto ela não pode esgotá-lo. Trata-se de ver a linguagem nascer do interior deste pano de fundo ontológico que é uma espécie de meio formador que possibilita o trabalho expressivo. Se a linguagem não é um dublê instrumental do pensamento, é porque a relação expressiva entre a fala e o pensamento deve ser considerada de modo positivo. Com $\mathrm{o}$ intuito de exprimir a profundidade e o alcance de nosso envolvimento enquanto falantes com a linguagem, o filósofo nos diz, em 1960, que "a linguagem não seria, segundo a expressão de Freud, um 'reinvestimento' total de nossa vida, o nosso elemento, como a água é o elemento dos peixes, se dublasse exteriormente um pensamento que em sua solidão dita regras para qualquer outro pensamento possível" (MERLEAUPONTY, 1996b, p.25).

A história do tema da linguagem na obra do filósofo francês não é desprovida de desvios e contornos. Porém, podemos encontrar formulações que revelam o interesse de condensar ao máximo estas duas ideias fundamentais. Tais formulações deixam transparecer um fio condutor 
para o intérprete. Merleau-Ponty não abre mão destas duas abordagens: por um lado, ele nunca abandona seu interesse pela linguagem se fazendo ou se realizando, momento em que há expressão da experiência silenciosa. Por outro, devemos abordar a linguagem adquirida de tal modo que ela reencontre seu lugar na experiência. A importância do lado criador da linguagem nunca será abandonada; já o lado sedimentado da linguagem será cada vez mais reconhecido como o reservatório inesgotável de tesouros para o falante. Em suma, é preciso reconhecer dois funcionamentos da fala: ou ela "pega, como o fogo pega", "ou pega mal e vira carvão” (MERLEAU-PONTY, 1953).

No início de sua carreira Merleau-Ponty investiga esta questão distinguindo duas camadas de significação da linguagem: por um lado, a camada empírica da fala falada, secundária, instituída e sedimentada; por outro, a camada transcendental, a fala falante, autêntica e instituinte. Ele aborda a intencionalidade lingüística em dupla dimensão: a dimensão sedimentada e a dimensão criadora em que o "poder de ordenar os estímulos e as situações está no seu auge no plano da linguagem” (MERLEAUPONTY, 1996, p.256). Para compreender a especificidade da linguagem em face da vida corporal é preciso chamar atenção para a sedimentação própria à atividade lingüística que, na Fenomenologia da percepção, é a "única, entre todas as operações expressivas, capaz de sedimentar-se e de constituir um saber intersubjetivo" (MERLEAU-PONTY, 1996, p.257). Este saber intersubjetivo é diferente do "saber primordial do "real"" (MERLEAU-PONTY, 1996, p.13) próprio à apreensão direta do mundo pela percepção. Esta apreensão inicial do mundo percebido é muda e anterior à linguagem elaborada e sedimentada.

Apesar de o filósofo insistir no fato de que não há "diferença fundamental entre os modos de expressão" (MERLEAU-PONTY, 1996, p.523), quando ele analisa a experiência linguística bem-sucedida podemos compreender qual é sua especificidade: ela "faz a significação existir como uma coisa no próprio coração do texto, ela a faz viver em um organismo de palavras, ela a instala no escritor ou no leitor como um 
novo órgão dos sentidos, abre para nossa experiência um novo campo ou uma nova dimensão" (MERLEAU-PONTY, 1996, p.248). ${ }^{1}$ Ao que tudo indica, a sutil diferença entre um modo de expressão e outro deve ser pautada na apreensão passageira do sentido perceptivo: a percepção não retém por tanto tempo suas sedimentações como a linguagem, além disto, ela não questiona seu saber adquirido. A relação entre o corpo e o mundo deixa o saber no nível da latência, daí apenas a suposição ou a suspeita de que uma determinação racional possa ler levada a diante. Já o saber presente na linguagem sedimentada pode ser "indefinidamente reiterado", ele pode ser retomado e interrogado por si mesmo: podemos falar sobre a fala, mas não pintar sobre a pintura. Ao falar, o sentido do que falamos está ancorado em nossa fala, mas tal sentido se encontra, também, operando em um universo já dado. Este segundo aspecto da fala "instala em nós a ideia de verdade como limite presuntivo de seu esforço. Ela se esquece a si mesma enquanto fato contingente, ela repousa sobre si mesma, e é isso que dá o ideal de um pensamento sem fala, enquanto a ideia de música sem sons é absurda" (MERLEAU-PONTY, 1996, p.258).

Eis aí o duplo aspecto da intencionalidade linguística: por um lado, não há pensamento prévio a expressão; por outro, a fala realiza uma aquisição, um saber que pode ser reiterado indefinidamente. Aqui, a fala se esquece enquanto fato contingente e faz aparecer um "privilégio da Razão". Donde a relação particular que a verdade estabelece com o tempo: para compreender este privilégio atribuído à razão devemos recolocar o pensamento entre os fenômenos da expressão e perceber que "na fala, melhor que na música ou na pintura, o pensamento parece poder separar-se de seus instrumentos materiais e valer eternamente" (MERLEAU-PONTY, 1996, p.523). Ora, esta ilusão é suscitada pela própria fala, afinal, depois de ter feito surgir seu significado, ela dissolvese e assume o papel de veículo neutro passando a gozar uma espécie de sobrevida. O que está em questão é a sedimentação que se exprime na fala, a qual é outra palavra para sua capacidade de eternização que é, ainda assim, uma "atmosfera do tempo" (MERLEAU-PONTY, 1996, p.526). Podemos dizer que na primeira filosofia de Merleau-Ponty o interesse teórico sobre a linguagem está voltado, principalmente, para o momento em que ela se inscreve no corpo e, se concentrando e se engajando em uma conduta, a existência "cai sob a percepção" (MERLEAU-PONTY, 
1996, p.485). Onde procurar o sentido da fala? Segundo Merleau-Ponty, o "sentido primeiro da fala está neste texto de experiência que ela tenta proferir" (MERLEAU-PONTY, 1996, p.425). Em 1945, o sentido da experiência lingüística é separado e posterior à consciência pré-reflexiva que está desde sempre em contato direto com o mundo percebido mudo.

O filósofo lança mão das ciências de sua época - psicologia, biologia, psicopatologia, neurologia - para investigar negativamente a linguagem viva ao nível de uma fenomenologia da percepção. É neste nível de análise que devemos nos situar se quisermos compreender suas primeiras teses. Para estudar o caráter fundamental da linguagem, ou seja, sua qualidade essencial de linguagem viva e produtiva, Merleau-Ponty analisa um caso de Gelb e Goldstein em que a linguagem serve apenas de instrumento. Em 1924 estes autores publicam um estudo sobre a amnésia dos nomes das cores: através desta pesquisa eles pretendem colocar em relevo o caráter categorial da experiência humana. Eles partem da observação de um caso que se tornou clássico: trata-se de um doente que perdeu tanto o sentido geral das cores, quanto a capacidade de nomear as cores. Tal paciente não se comporta mais de maneira categorial, ele não consegue mais classificar as cores segundo um princípio abstrato, ele não as organiza em função de seus nomes. Este transtorno exprime uma alteração da conduta perceptiva: a percepção das cores. ${ }^{2}$ Goldstein interpreta este fenômeno como expressão de uma modificação do comportamento simbólico ou representativo adotado pelo paciente diante da cor. $\mathrm{O}$ paciente perde o controle de seu comportamento categorial, ele não consegue mais achar os nomes das cores como representantes das próprias cores, elas perdem sua espessura representativa. Já o homem normal considera um objeto concreto como representante de uma categoria: seu comportamento é categorial. O que tais autores têm em mente é o fato de que apesar dos pacientes chegarem a utilizar as palavras equivalentes aos nomes das cores ou mesmo pronunciar tais nomes, a atitude categorial lhes permanece inacessível. ${ }^{3}$

Ao comentar este caso de afasia amnésica, Merleau-Ponty nos diz que a situação do doente está reduzida à "experiência imediata das relações" (MERLEAU-PONTY, 1996, p.260). O doente não usa mais o material fornecido pela experiência sensível e linguística do mesmo modo que o normal, "ele jamais usa a linguagem para exprimir uma situação apenas 
possível" (MERLEAU-PONTY, 1996, p.265). O paciente não experimenta mais a mesma rede intencional de equivalências e correspondências que o homem normal, o qual sempre pode ser motivado por uma tarefa atual e possível. Segundo a interpretação merleau-pontiana, "a atividade categorial, antes de ser um pensamento ou um conhecimento é certa maneira de relacionar-se ao mundo e, correlativamente, um estilo ou uma configuração da experiência" (MERLEAU-PONTY, 1996, p.259). Se assim for, o paciente se torna incapaz de usar o nome de forma categorial porque ele sofreu um abalo radical tanto no meio concreto de sua experiência, quanto na capacidade de figurar uma intenção significativa. Para comentar o que está em questão na doença Merleau-Ponty emprega termos kantianos para que o leitor acostumado com o debate da época compreenda o ponto: a doença "afeta menos o entendimento do que a imaginação produtora". O doente não utiliza nem o vocabulário nem a sintaxe do mesmo jeito que o homem normal. Com o empobrecimento ou o estreitamento da experiência o que se tem em mira é a produtividade que o normal possui e que o doente perde. O sentido das falas de tais pacientes encontra-se "imobilizado". Já no jogo corrente da linguagem normal, todos os níveis se realizam e se interpenetram, e isto, segundo uma escala que vai da forma mais automática e concreta à forma mais reflexiva e ideativa do discurso. Segundo Goldstein, a linguagem do adulto normal possui uma "extraordinária independência" e uma "extraordinária riqueza” (GOLDSTEIN, 1969). ${ }^{4}$ Em contraste com o homem normal, podemos compreender que há casos em que o paciente "não sente necessidade de falar, sua experiência nunca tende para uma fala, nunca suscita nele uma questão, ela não deixa de ter este tipo de evidência e de suficiência do real que abafa toda interrogação, toda referência ao possível, toda surpresa, toda improvisação" (MERLEAU-PONTY, 1996, p.266). A linguagem tal como expressa pelo doente apresenta apenas um caráter concreto e está subordinada à ação e ao real. A gênese da linguagem em situações como esta mostra que em pacientes acometidos de tais distúrbios ela só se presta a uma utilização instrumental. Não se trata, segundo Goldstein, de negar que o homem normal a utilize e que ela seja realmente indispensável para a edificação da civilização humana,

"mas esta função de instrumento supõe que a linguagem signifique, no fundo, algo inteiramente diferente ou, como no doente, que ela outrora, antes da 
doença, significava algo completamente diferente. A função instrumental da linguagem supõe a função representativa, quer dizer, uma atitude geral muito determinada, a atitude simbólica e categorial. Sem esta atitude, a linguagem do homem não seria, de forma alguma, uma linguagem" (GOLDSTEIN, 1969).

Frisemos o fato de que nestes casos não há perda do estoque de palavras ou dos movimentos, mas perda de certo tipo de ato ou comportamento verbal e motor. Perde-se certo nível de ação na percepção: o sentimento espontâneo, a ação voluntária, a linguagem abstrata. Perde-se a capacidade de tomar uma coisa como representante de outra e passa-se a utilizar a linguagem apenas como instrumento. Daí a deficiência, a modificação, ou ainda, a perda daquela função fundamental. Merleau-Ponty nos diz que "o ato categorial não é um fato último, ele se constitui em certa 'atitude' (Einstellung). É nessa atitude que a fala também está fundada, de forma que não poderia se tratar de fazer a linguagem repousar no pensamento puro" (MERLEAU-PONTY, 1996, p.224). Percebe-se o interesse merleau-pontiano de inscrever a função categorial da linguagem no interior de uma orientação corporal, ou antes, em uma posição do corpo em relação ao mundo. É do interior da percepção que nasce a intenção significativa da linguagem. Nos casos discutidos, o comportamento está reduzido a atitudes imediatas e a operações concretas: o paciente responde apenas situações efetivas, ele não maneja as palavras para designar conceitos. Nesses casos o pensamento e a linguagem são "cortados de seu sentido vivo", o qual se exprime, precisamente, na "relação essencial entre a linguagem e o pensamento" (MERLEAU-PONTY, 1996, p.261). Quando, na vida de um indivíduo doente, a palavra "perde seu sentido, modifica-se até em seu aspecto sensível, ela se esvazia" (MERLEAUPONTY, 1996, p.261). A potência de formulação simbólica presente na linguagem se desestrutura e o material linguístico se empobrece consideravelmente. Depois destas análises o filósofo é levado a reconhecer, em princípio, uma significação gestual, um sentido existencial da fala; em seguida, ele defende a tese de que o interior da linguagem não é um pensamento fechado sobre si, mas sim "tomada de posição do sujeito no mundo de suas significações” (MERLEAU-PONTY, 1996, p.262). Ora, a inerência da linguagem ao corpo não exclui seu sentido abstrato. Quan- 
do falamos, é todo o aparato corporal que trabalha para levar a cabo a comunicação. Merleau-Ponty vê algo de inexplicável, ou melhor, de "miraculoso" no problema da linguagem: "uma contração da garganta, uma emissão de ar sibilante entre a língua e os dentes, certa maneira de desempenhar de nosso corpo deixam-se repentinamente investir de um sentido figurado e o significam fora de nós" (MERLEAU-PONTY, 1996, p.262). A condição sensível para que este milagre da comunicação e da instauração do sentido aconteça - a condição para que a intenção de falar se realize -, consiste em que "a gesticulação fonética utilize um alfabeto de significações já adquiridas, que o gesto verbal se execute em certo panorama comum de interlocutores". Mas só isto não basta. Após imergir a fala no corpo é preciso fazê-la se diferenciar dele. A fala é criadora em sua gesticulação faz nascer um sentido novo. Para caracterizar esta gesticulação significativa Merleau-Ponty nos diz que ela é uma "potência aberta e indefinida de significar - quer dizer, ao mesmo tempo de apreender e de comunicar um sentido". Assim, em contraste com a orientação categorial na qual a fala está fundada é possível compreender que esta "potência irracional" é "o fato último pelo qual o homem se transcende em direção a um comportamento novo, ou em direção ao outro, ou em direção ao seu próprio pensamento, através de seu corpo e de sua fala" (MERLEAU-PONTY, 1996, p.262). Este fato último está aquém de todos os atos particulares nos quais ele se engaja.

O estudo da patologia da linguagem leva o filosofo à conclusão de que há uma ambiguidade inultrapassável da linguagem, pois ela é "integralmente motricidade e integralmente inteligência”. No normal há sempre uma diferenciação daquilo que é a figura e daquilo que é o fundo na linguagem, ele pode mudar o valor atribuído tanto a um quanto a outro porque para ele figura e fundo não estão no mesmo nível. De forma que no homem normal há uma relação muito variada entre as duas camadas de significação da linguagem. $\mathrm{Na}$ vida normal da linguagem, a relação entre o ato de fala e a potência falante aponta para um ser novo. Por contraste com a experiência patológica é possível saber qual é, então, a "essência da linguagem normal: a intenção de falar só pode encontrar-se em uma experiência aberta; ela aparece, assim como a ebulição em um líquido, quando, na espessura do ser, zonas de vazio se constituem e se deslocam para o exterior" (MERLEAU-PONTY, 1996, p.266). 
A comparação da intenção de falar nascendo do interior da água fervente é recorrente na filosofia de Merleau-Ponty. Aqui, a origem das falas é comparável ao surgimento das bolhas no interior de um líquido fervente porque assim como as bolhas, as falas não se encontravam lá desde sempre, mas graças à fervura, elas aparecem como que por milagre do fundo da água quente. Com a motivação específica, a fala rompe com a plenitude do líquido fervente, ela se diferencia dele. A existência muda - sempre em contato consigo mesma antes dos atos particulares - é motivada a produzir atos que a excedem e sem os quais não seria possível conhecê-la. Ela faz isto formando zonas de vazio, de não-ser, que são excessos em relação àquilo que é e já foi dito. Em 1945, a metáfora da ebulição procura traduzir uma experiência ambígua de indiferenciação e de diferenciação, ou antes, de continuidade e de descontinuidade: as bolhas produzidas pela fervura excedem a água fervente. A fala coloca o seguinte problema: aberto a fenômenos que ultrapassa o falante, tais fenômenos só existem na medida em que ao falar ele os retoma e os vive.

Se levarmos em conta aquilo que há de contingente na expressão e na comunicação, se prestarmos atenção na criança que aprende a falar ou no escritor que "diz e pensa pela primeira vez alguma coisa", compreenderemos que há uma operação primordial que "transforma certo silêncio em fala". Ora, quem opera no registro da fala falada ou instrumental supõe "o passo decisivo da expressão" e não vai além de uma "visão superficial do homem". Mas se quisermos investigar aquela potência de significar que, segundo a expressão de Goldstein, "forma a essência mais profunda do homem", devemos, como quer Merleau-Ponty, por um lado, remontar à origem do ato expressivo e reencontrar, "sob o ruído das falas, o silêncio primordial"; por outro, devemos descrever "o gesto que rompe esse silêncio” (MERLEAU-PONTY, 1996, p.250). 5 Trata-se de reconhecer aqui um passo metodológico importante: em 1951 Merleau-Ponty nos conta que na Fenomenologia da percepção ele procedia a uma espécie de "abstração metódica" na qual ele "fingia" encontrar-se, inicialmente, no "mundo mudo da percepção" (MERLEAU-PONTY, 2000, p.22). ${ }^{6}$ Ele faz isto para que a pesquisa caminhe de tal forma que o mundo da percepção pareça como anterior a todo objeto cultural sedimentado e, em particular, à linguagem. Situando-se nesta região muda da experiência em que o sujeito finge não ter balizas culturais para se apoiar, o filósofo interpreta o 
nascimento do sentido da linguagem como o aparecimento do não ser no do interior da plenitude do ser. $\mathrm{O}$ ato da fala, ou melhor, o falar, é compreendido como excesso que rompe o silencio da experiência muda. Compreendido como a passagem violenta entre o silêncio e a linguagem, o ato de fala surge sob o fundo de uma consciência silenciosa que se encontra situada na percepção, a qual não é apenas pressuposta pelos atos, mas é, também, "o fundo sobre o qual todos os atos se destacam" (MERLEAU-PONTY, 1996, p.6). O fato último precisa de pontos de apoio no mundo sensível em relação aos quais ele seja um excesso. $\mathrm{O}$ sentido novo "não pode ser definido por nenhum objeto natural; é para além do ser que [a existência] procura alcançar-se e é por isso que [ela] cria a fala como apoio empírico de seu próprio não ser. A fala é o excesso de nossa existência por sobre o ser natural" (MERLEAU-PONTY, 1996, p.267).

Os leitores da Fenomenologia da percepção sabem que o "fato último" se identifica com o "cogito tácito", condição da linguagem. Através deste conceito o filósofo pretende designar uma experiência originária em que o sujeito mantém uma relação muda tanto consigo mesmo quanto com o mundo e os outros. É a linguagem que deve ser requisitada a exprimir esta experiência muda. A linguagem aparece como derivada ou segunda em relação ao cogito tácito: a linguagem articulada seria um produto derivado e secundário.

“As essências separadas são as da linguagem. É função da linguagem fazer as essências existirem em uma separação que, na verdade, é apenas aparente, já que através da linguagem as essências ainda repousam na vida antepredicativa da consciência. No silêncio da consciência originária, vemos aparecer não apenas aquilo que as palavras querem dizer, mas ainda aquilo que as coisas querem dizer, o núcleo de significação em torno do qual se organizam os atos de denominação e de expressão" (MERLEAU-PONTY, 1996, p.12).

Em contraste com o núcleo unificante da consciência, os atos particulares do sujeito são posteriores. Para saber o que é a consciência MerleauPonty apela, então, para uma experiência que vem antes de todas as outras e que nos permite ter acesso direto e imediato àquilo que o próprio mundo exprime (espécie de "meio direto de termos acesso àquilo que [a 
consciência] significa"): "nós temos a experiência de nós mesmos, dessa consciência que somos, e é a partir dessa experiência que se medem todas as significações da linguagem, é justamente ela que faz com que a linguagem queira dizer algo para nós" (MERLEAU-PONTY, 1996, p.12). O cogito tácito é este núcleo unificante anterior às sedimentações, ele está "antes de toda fala". Antes do "cogito falado" - pensamento convertido em enunciado e em verdade de essência - encontramos o "cogito tácito" que condiciona a linguagem. Esta "experiência de mim por mim" é anterior e torna possível a linguagem. É desse modo que a linguagem passa a ter um papel secundário em relação a esta consciência perceptiva silenciosa. Os sentidos das palavras "brotam" do "comércio com o mundo e com os outros homens que o habitam"; deste comércio originário mudo as significações da linguagem são uma tradução em palavras; esta relação profunda com o mundo e os outros fornece "o texto do qual nossos conhecimentos procuram ser a tradução em linguagem exata" (MERLEAU-PONTY, 1996, p.16). É o caso, por exemplo, da ciência que ao procurar integrar nosso corpo ao tecido de relações objetivas "traduz", ao seu modo, "a sutura entre meu corpo fenomenal e o mundo primordial” (MERLEAU-PONTY, 1996, p.469). Esta tradução de que fala o filósofo são atos nos quais a própria existência se concentra com o intuito de se ultrapassar.

Eis aí o paradoxo que não encontra solução no registro de uma fenomenologia da percepção, ou antes, tal paradoxo não encontra solução no interior da tematização daquilo que o filósofo chama em seu período intermediário de "má ambiguidade" que só chega a misturar os extremos e termina não vendo muito bem como de fato eles se ligam: como compreender que haja um pensamento tácito que é anterior a tudo o que existe e ao mesmo tempo só se conhece através da linguagem? Para compreender como se liga estas duas pontas da cadeia é preciso apontar para algumas ideias presentes nos textos do período intermediário sobre a fenomenologia da linguagem. É verdade que o estudo da percepção natural coloca Merleau-Ponty em posse de um "método aplicável a novos problemas" (MERLEAU-PONTY, 2000, p.23). Mas é verdade, também, que estes novos problemas - a linguagem, o conceito, o mundo cultural - o levam além das ideias desenvolvidas neste primeiro período fazendo, enfim, com que haja uma revisão de suas primeiras aquisições 
conceituais. Há, ainda, o desconforto da estrutura do argumento desenvolvido na Fenomenologia da percepção que deve ser indicado. É a revisão desta tensão que o filósofo começa a empreender quando investiga a passagem das significações presentes na percepção para aquelas que caracterizam o mundo cultural. Como reconhecer tal desconforto? Para isto é preciso lembrar o modo como se relacionam o ato particular finito e a potência irracional de criar e comunicar significações. Não podemos simplesmente superpor um ao outro, pois sua relação é de fundação: o cogito tácito é primeiro no sentido em que o ato da fala se apresenta como uma determinação ou uma explicitação sua; graças a isto, o ato de fala não esgota o cogito tácito. Mas este cogito não é primeiro no sentido empirista, nem o ato de fala é simplesmente derivado dele, afinal, é através do ato de fala que o cogito tácito se manifesta. Trata-se de compreender duas teses que, finalmente, são difíceis de conciliar por causa da característica da análise. Merleau-Ponty afirma simultaneamente duas teses que ele procura conciliar em uma dimensão única aquém da determinação: há, ao mesmo tempo, a expressão das vivências do corpo em situação através da linguagem, e a existência de um sentido que é obtido pela ruptura, através da linguagem, do silêncio da consciência. A linguagem como expressão do ser no mundo deve, para se realizar, romper o silêncio do ser para si.

O paradoxo é difícil de ser solucionado porque a significação gestual depende do cogito tácito. Não há sobreposição da experiência muda e da experiência linguística: há correlação rigorosa entre o corpo e o mundo, isto é, há correlação entre as estruturas do corpo e o mundo natural, assim como há correlação entre as estruturas significativas da fala e do mundo cultural. Além disto, não há prioridade cronológica entre o cogito e a fala, nem a fala é derivada causalmente do cogito: há fundação. O problema está em que mesmo depois de haver inscrito o sentido da linguagem no mundo sensível, o filósofo tem que apelar para a ideia de ruptura para explicar a passagem da experiência individual muda para a comunicação no mundo das instituições humanas. Em 1945, a fundação e a correlação dão a tônica da mediação. Se todo ato particular de fala se funda na relação silenciosa que o sujeito da percepção mantém consigo mesmo, resta que este silêncio deve ser reconquistado e expresso através do próprio ato particular de fala. A maneira menos enigmática de 
exprimir esta relação é dizendo que ela é circular: a fala exprime o silêncio, mas o próprio silêncio só vem à tona graças à fala.

\section{II}

Ao abordar a passagem do sentido perceptivo ao sentido presente na linguagem, assim como ao estudar a novidade da expressão linguística em relação às expressões mudas, em seu período intermediário MerleauPonty atribui um papel à fala que é análogo àquele desenvolvido pelo corpo em 1945, a saber, o de "mediador de um mundo" (MERLEAUPONTY, 1996, p.201). Nos textos publicados logo depois da segunda guerra mundial, o sujeito que fala é quem produz as significações inéditas. No início dos anos 50, a caracterização da fala como veículo de nosso movimento em direção à verdade não exprime o abandono completo das teses anteriores sobre o corpo. O filósofo se interessa, agora, pela articulação entre figura e fundo em um nível superior: "é preciso perseguir em um nível superior a descrição que a Gestalt deu da 'significação’ perceptiva” (MERLEAU-PONTY, 1953). Trata-se, portanto, de uma retomada e um ultrapassamento do estudo da percepção. O problema da linguagem aparece, então, como um "problema especial”, pois ele "contém todos os outros, inclusive o da filosofia" (MERLEAU-PONTY, 1996b, p.116).Vem daí a retomada sistemática do estudo da linguagem e da fala. Se por intermédio da primeira temos acesso ao mundo natural e cultural, pela segunda fazemos a passagem das intenções significativas mudas presentes no mundo da percepção àquelas presentes no mundo cultural. Através da linguagem os homens coexistem e se comunicam. Pela fala reencontramos o "gesto ambíguo que forma o universal com o particular, o sentido com nossa vida” (MERLEAU-PONTY, 1999, p.203). Na ordem dos trabalhos do filósofo, depois de abordado ao nível da fenomenologia da percepção, o falante é investigado através de uma fenomenologia da fala inseparável de uma fenomenologia da linguagem. Ao redor desta problemática é possível ver o relevo que adquire o fenômeno da expressão, afinal ele deve ser compreendido como "o momento humano por excelência" em que "uma vida tecida de acasos se volta sobre si mesma, se reassume e se exprime” (MERLEAU-PONTY, 1999, 
p.305). Merleau-Ponty aponta para uma espécie de sublimação da corporeidade que põe em relevo a operação do espírito: retomada da existência corporal individual e particular em um movimento que a prolonga com o intuito de significar. A significação comum que se exprime na linguagem é feita de significações abertas e, ao falar, é todo o contato particular do falante com o mundo linguístico que é posto em andamento. Aqui, o corpo se abre a uma gesticulação própria que só pode ser compreendida através da língua falada.

O período intermediário da filosofia de Merleau-Ponty retoma o estudo da ciência da linguagem para extrair conseqüências que resvalam não só sobre o ser da linguagem, mas também em sua própria filosofia. $\mathrm{O}$ praticante da boa filosofia fenomenológica não objetiva as línguas existentes diante de uma consciência constituinte universal e intemporal. Ele investiga o contato do falante com a língua falada; ele encontra uma dimensão em que a observação científica e a atividade falante não são contraditórias, mas solidárias e possíveis, realizando a comunicação. Podese resenhar a importância da lingüística para a filosofia desde 1947: ela orienta a pesquisa filosófica na direção de uma "revisão das relações do sujeito com o objeto” (MERLEAU-PONTY, 1966, p.151). É a própria ciência da linguagem que nos ensina que a língua não pode ser objetivada, que não devemos nos colocar diante dela como se ela fosse inteiramente exterior. Não podemos decompor a língua e depois estabelecer uma somatória de seus acidentes como faz o cientista tradicional. Não basta interpretar a língua no interior da alternativa entre a ciência (exterioridade, decomposição, somatória) e filosofia (consideração exclusiva do sujeito que usa a língua como falante). Se não podemos opor a linguagem como objeto do pensamento e a linguagem do sujeito falante, não podemos, também, superpô-las. O que se procura é uma mediação entre a filosofia e a ciência da linguagem: "esta mediação do objetivo e do subjetivo, do interior e do exterior que procura a filosofia, nós poderíamos encontrar na linguagem se nós conseguíssemos aproximar bem perto dela" (MERLEAU-PONTY, 2001, p.87). A experiência da fala guarda um ensinamento filosófico: ela tem um alcance ontológico, através dela podemos compreender o ser da linguagem e do falante, já que ambos se realizam graças à relação entre a objetividade linguística e a individualidade de quem usa os instrumentos linguísticos. 
Merleau-Ponty propõe um duplo ponto de vista para analisar o fenômeno da linguagem: um ponto de vista subjetivo que envolve o ponto de vista objetivo e um ponto de vista objetivo que envolve o ponto de vista subjetivo. Dito nos termos da ciência da linguagem: a sincronia envolve a diacronia e a diacronia envolve a sincronia. Por um lado, o indivíduo tem todo o passado da linguagem se fazendo presente quando ele fala; a língua é tomada em um corte transversal, ela é um todo, um sistema. Por outro, a língua é tomada em um corte longitudinal em que a sucessão dos tempos e a seqüência dos acontecimentos fortuitos da língua fazem com que ela comporte acasos. ${ }^{7}$ Enfim, não há língua sem fala, assim como não há fala fora da língua. Esta espécie de troca entre a língua e a fala se faz no interior de uma ação linguística. A assunção deste duplo ponto de vista radicado na práxis implica em uma "dupla tarefa": por um lado, é preciso encontrar um sentido no desenvolvimento da linguagem e interpretá-la como um equilíbrio em movimento; por outro, devemos compreender que se as significações da linguagem são abertas é porque o sistema que se realiza na sincronia "nunca está inteiramente em ato, ele comporta sempre mudanças latentes ou em encubação". Na ação linguística a perspectiva subjetiva e a perspectiva objetiva se comunicam. Segundo Merleau-Ponty a fenomenologia da linguagem ensina a reconhecer uma "nova concepção do ser da linguagem que é, agora, lógico na contingência, sistema ordenado que, no entanto, sempre elabora acasos, retomada do fortuito em uma totalidade dotada de sentido, lógica encarnada" (MERLEAU-PONTY, 1996b, p.110).

Os elementos que compõem a cadeia verbal não podem ser interpretados apenas de modo positivo. Os elementos linguísticos, ou melhor, os vocábulos de uma língua, "fazem sistema no sentido em que cada um deles só significa sua diferença em relação aos outros” (MERLEAUPONTY, 1996b, p.110). Uma vez que os signos ou os elementos da língua são diacríticos, resta que "na língua só há diferença de significação". Quando falamos, as palavras da frase não têm em si mesmas um significado positivo. Tomadas isoladamente elas não significam nada além daquilo que diz o dicionário. $O$ fenômeno da linguagem deve ser apreendido como aquele momento em que o falante imprime uma torção nas palavras e na sintaxe ordinária fazendo alusão a uma significação aberta que não é conceitual. As palavras não têm um sentido 
autônomo, elas só significam e nós só podemos reconhecê-las graças às relações laterais e obliquas que elas estabelecem entre si.

Para compreender as torções que imprimimos na linguagem instituída quando falamos é preciso insistir no fato de que são elas que conduzem a intenção do falante à sua encarnação na fala. Trata-se de explorar esta organização dos sistemas de signos que faz com que um falante entre em contato com alguém. É a linguagem instituída que fornece as condições necessárias para a fala, ela fornece um fundo de comunicação dada no interior do qual se move o falante que reconhece as significações disponíveis na linguagem como familiares. Retomemos esta intenção prática que caracteriza o estilo, o qual se lê no uso particular da linguagem e exprime a intenção de quem fala. Quando o filósofo volta a investigar a relação da potência falante e do ato de falar, ele lança mão, através dos trabalhos de Goldstein, de uma noção própria ao pensamento de W.Von Humboldt: a noção de "forma interior da linguagem" (innere Sprachform). ${ }^{8}$ Ao investigar o mecanismo através do qual o pensamento se encarna na linguagem instrumental, Merleau-Ponty nos diz que foi exatamente isto que Goldstein encontrou neste conceito de Humboldt. Antes de estudar esta noção, vejamos a razão deste aprofundamento da análise.

Em 1948, Goldstein publica um livro - Linguagem e distúrbios da linguagem - que revela uma autocrítica de seu pensamento. As teses presentes neste livro ajudam Merleau-Ponty não só a progredir em suas pesquisas, mas também retificar o modo como compreende a relação entre a consciência e a linguagem. Um ano depois de sua publicação, o filósofo retoma algumas de suas consequências em um curso sobre patologia da linguagem. Após afastar as interpretações alternativas da afasia (Broca e as primeiras teses de Goldstein: o primeiro porque trata a linguagem como soma de engramas cerebrais, o segundo porque encontra atrás da função lingüística um poder de pensamento), ele nos diz que para que o fenômeno lingüístico receba a atenção que merece no interior de uma teoria da afasia é preciso "determinar os papéis respectivos do condicionamento corporal" e da "consciência intelectual" (MERLEAU-PONTY, 2001, p.62)..$^{9}$ De fato, em seus melhores momentos a teoria de Goldstein não orienta o pesquisador em direção ao idealismo, isto Merleau-Ponty já sabia em 1945. Porém, neste novo livro as teses de Goldstein se tornam 
mais precisas: "ele redefine a atitude categorial, depois introduz uma noção nova: a noção de instrumento linguístico (instrumentalities of speech). Ele mostra que estas duas funções são estreitamente dependentes uma da outra, que a perda desta prejudica aquela" (MERLEAU-PONTY, 2001, p.63). Inicialmente, a atitude categorial era compreendida em termos kantianos, agora, ela supõe o funcionamento de uma paisagem cultural que a liga indissoluvelmente à linguagem articulada. Esta forma de linguagem passa a chamar a atenção do filósofo, pois é graças a sua capacidade de "manejar símbolos vazios" que se pode ir além dos gestos e dos gritos, os quais trazem apenas um "aumento de sentido a uma situação dada”. A ligação da atitude categorial e da linguagem articulada chama atenção para a especificidade da expressão lingüística: temos aqui uma atividade expressiva que evoca seu próprio contexto e induz a situação mental da qual ela procede. É este fator de mediação que é preciso reconhecer na linguagem. A ausência desta mediação fazia com que a perspectiva inicial de Goldstein permanecesse tradicional exatamente na medida em que suscitava uma distinção entre os dois tipos de linguagem. É neste momento que precisamos perguntar, como faz Merleau-Ponty no início dos anos 50, se Goldstein não terminaria por "colocar a significação na linguagem como o piloto em seu navio" (MERLEAU-PONTY, 1968, p.37). ${ }^{10}$ Da relação de exterioridade decorrente da distinção é preciso passar, então, à "ligação entre as duas ordens" (MERLEAU-PONTY, 1968, p.37). Doravante, o pesquisador não é mais levado à "bipartição clássica entre o corporal e o espiritual” (MERLEAU-PONTY, 2001, p.63). O que interessa a Merleau-Ponty é colocar em relevo ao mesmo tempo a "osmose das duas funções" e o papel do pensamento em cada uma delas. O espírito permanece para sempre dependente do material linguístico que o impulsiona a ir além dos instrumentos da linguagem.

"Não há de um lado a significação e de outro os instrumentos (instrumentalities) da linguagem, com o passar do tempo, os instrumentos só permanecem utilizáveis se a atitude categorial é conservada e inversamente a degradação dos instrumentos comprometem a apreensão da significação. Existe, então, um espírito da linguagem e o espírito é sempre carregado de linguagem. A linguagem é o sistema de diferenciações no qual se articula a relação do sujeito e do mundo" (MERLEAU-PONTY, 1968, p.37). ${ }^{11}$ 
Não se trata de dizer que o espírito constitua os instrumentos linguísticos: em um mesmo gesto ele os reanima, insufla-lhes vida nova e vai além. Os traços deixados pelos atos de expressão são utilizados pelo espírito: ele reativa os instrumentos da linguagem. Podemos trabalhar com as sedimentações sem reativar seu sentido, porém, é "impossível separar mesmo idealmente o espírito de suas raízes, a significação e a linguagem em sua forma específica, seu modo de organização. A significação é o espírito da cadeia verbal" (MERLEAU-PONTY, 1953). A fala interpretada como instrumento de atualização do pensamento só se realiza verdadeiramente no momento em que se incorpora em uma expressão verbal determinada: sob estas condições a linguagem se torna o “veículo do pensamento" (MERLEAU-PONTY, 2001, p.65). É para compreender este mecanismo de encarnação que os estudiosos da linguagem lançam mão do pensamento de Humboldt. A noção de "forma interior da linguagem" não nos remete a uma linguagem interior que evocaríamos através de imagens verbais. Através desta noção aprendemos a reconhecer a perspectiva de mundo que habita a linguagem. Merleau-Ponty nos diz que graças a esta noção temos "o reflexo na linguagem da perspectiva sobre o mundo própria a uma cultura" (MERLEAU-PONTY, 2001, p.65). Não podemos mais sustentar a alternância entre a potência falante e o mundo da linguagem. Quando falamos, a forma interior da linguagem mobiliza a totalidade dos processos e das expressões presentes no mundo cultural. Este conceito permite exorcizar o fantasma da anterioridade do espírito em relação à linguagem. A potência falante não é a soma das significações da linguagem, nem o ato de fala supõe uma correspondência prévia entre a intenção do falante e o arranjo objetivo das expressões utilizadas. $\mathrm{O}$ pensamento é tributário de um ato linguístico. Merleau-Ponty faz questão de enfatizar a dependência do espírito em relação a este "organismo de palavras que ele criou, ao qual ele continua a insuflar vida, e que, todavia, lhe impulsiona como se ele fosse dotado de uma vida própria" (MERLEAU-PONTY, 1968, p.38). Se "toda linguagem é espírito”, resta que este espírito não é um para si, mas "um espírito que se possui apenas perdendo-se na linguagem” (MERLEAU-PONTY, 2001, p.67).

"Quando falo, as palavras, os meneios necessários para conduzir à expressão minha intenção significativa são-me recomendados apenas 
graças ao que Humboldt chama de innere Sprachform (e que os modernos chamam de Wortbegriff), isto é, graças a certo estilo de palavras de que dependem e por cujo intermédio se organizam sem que eu precise representá-los a mim. Há uma significação 'linguageira' da linguagem que executa a mediação entre minha intenção ainda muda e as palavras, de tal sorte que minhas palavras surpreendem a mim mesmo e me ensinam meu pensamento. Os signos organizados têm seu sentido imanente, e este não depende do 'eu penso', mas do 'eu posso"' (MERLEAU-PONTY, 1996b, p.110-111).

A potência falante e o ato de falar passam a se relacionar através de uma significação que realiza a mediação entre aquilo que o falante quer dizer e o modo que ele diz: "a junção do pensamento puro e da linguagem se faz então na 'innere Sprachform'. [...] Entre a linguagem, como soma de palavras, e o pensamento, se interpõe uma camada de significações que supõe certa relação com ele.É esta espécie de pensamento na linguagem, não explícita, que constitui o estilo" (MERLEAU-PONTY, 2001, p.65). ${ }^{12}$ A significação situacional que habita a linguagem é retomada pelo falante com o intuito de significar para além das significações disponíveis. A vida significativa da linguagem deve ser compreendida no sentido em que Humboldt nos diz que a linguagem é energeia e não ergon, isto é, ela não é algo pronto, um fenômeno estático, mas um processo contínuo e dinâmico no qual os sons usados exprimem pensamentos. ${ }^{13} \mathrm{O}$ essencial da fala consiste no fato de falar, de exprimir um pensamento. Como compreender este processo dinâmico operando na linguagem? Humboldt nos diz que não se trata de "uma faculdade especial, mas da aptidão intelectual inteiramente aplicada ao uso da linguagem, o princípio interno que rege a linguagem e dá por todo lado a impulsão dirigente" (HUMBOLDT, apud GOLDSTEIN, 1969). Se a linguagem for interpretada apenas como um meio exterior para designar uma realidade préexistente, não compreenderemos que ela possa organizar e exprimir o mundo circundante e cultural.

No início dos anos 50 Merleau-Ponty nos diz que esta "ação à distância da linguagem" deve ser interpretada como um "caso eminente da intencionalidade corporal” (MERLEAU-PONTY, 1996b, p.111). Há uma analogia profunda que o filósofo quer estabelecer entre dois tipos de 


\section{4}

relação: a relação do corpo e de sua paisagem sensível, e a relação da fala e de sua paisagem cultural. A consciência que o sujeito da percepção tem do alcance de seus gestos não é muito diferente da consciência do sujeito falante, afinal, a fala "é pregnante de uma significação que pode ser lida na própria textura do gesto linguístico” (MERLEAU-PONTY, 1996b, p.111). O gesto perceptivo exprime a potência simbólica do corpo. O gesto não é um movimento mecânico, ele também não é atividade de um ego, ele é da ordem do advento. ${ }^{14}$ Quem gesticula não é uma consciência constituinte, mas uma maneira de se engajar no mundo, ou melhor, é um sujeito encarnado. Quando há expressão é porque o gesto surge, no próprio ato de expressão, como já lançado no mundo e investido por ele. Para sublinhar aquilo que o gesto corporal tem em comum com o gesto lingüístico é preciso dizer que em ambos há articulação entre o sentido e a situação que motiva o gesto. Já o que os distingue deve ser procurado na especificidade do meio no qual eles estão inseridos. O meio do gesto corporal é o mundo sensível, do qual ele é uma efêmera encarnação. Já o meio do gesto linguístico surge em um duplo movimento: por um lado, ele surge no mundo como uma primeira camada de significação; por outro, ele surge no universo dos signos sedimentados ou da língua como uma espécie de concentração do universo dos signos, momento em que sua significação conceitual se inscreve na ordem da cultura. Assim, não se trata apenas de designar uma perspectiva que articula o mundo físico e social, mas também de indicar que há aí o nascimento de algo novo.

O perfil desta intenção significativa pode ser identificado desde que, no sujeito falante, ela seja um excesso, um "vazio determinado a ser preenchido por palavras” (MERLEAU-PONTY, 1996b, p.112). O sentido veiculado pelo falante não está nem no seu material expressivo nem no próprio sujeito falante. Em princípio, as significações presentes na linguagem são abertas, em seguida, o trabalho expressivo não termina; enfim, o ato de expressão não é para o falante uma operação segunda, mas “a aquisição de significações” (MERLEAU-PONTY, 1996b, p.112). Para descrever esta operação Merleau-Ponty nos diz que "a intenção significativa se dá um corpo e se conhece a si mesma buscando um equivalente no sistema das significações disponíveis, que representam a língua [que o sujeito falante fala] e o conjunto dos escritos e da cultura de que é herdeiro" (MERLEAU-PONTY, 1996b, p.113). Quem fala age em um 
mundo em que se encontram disponíveis os meios de expressões linguísticos. Se o falante não vai além da linguagem falada ("aquela que é adquirida, e que desaparece ante o sentido do qual ela tornou-se portadora”) ele não dá a pensar, ele não suscita nada de diferente. Mas se ele usa a linguagem falante ("aquela que se faz no momento da expressão, que vai me fazer escorregar dos signos ao sentido" [MERLEAUPONTY, 1999, p.17]) é porque ele imprime certa organização ou "deformação coerente" no sistema dos signos sedimentados que lhe permite estabelecer uma relação com um interlocutor.

A significação da linguagem é a combinatória particular dos signos disponíveis. É neste contexto que Merleau-Ponty julga "legítimo recusar as perspectivas que apresentariam o mundo das instituições e da linguagem como segundo e derivado em relação ao mundo da natureza, e viver em uma espécie de religião do homem" (MERLEAU-PONTY, 1999, p.60). Desde então, quando há inversão da expressão do mundo sensível mudo para a expressão do mundo cultural e histórico, o "sentido ágil" que a linguagem exprime exige outras categorias para ser interpretado. Como compreender o duplo movimento que faz com que a idealidade ou a significação expressa na linguagem esteja radicada em um espaço e em um tempo que a faz existir, mas ainda assim institua uma dimensão nova que pode ser indefinidamente reiterada? Como figurar a relação entre o indivíduo e a instituição da linguagem? Merleau-Ponty nos diz que "este vazio de sentido preparou-se no pleno da vida individual, como a ebulição na massa d'água, tão logo o que se sentiu coagulou-se em coisas" (MERLEAU-PONTY, 1999, p.61). O sentido da linguagem se esboça através de uma vida individual que o transforma, ele nasce na fala quando esta retoma as condições do aparelho natural e linguístico e os metamorfoseia. O movimento matizado nesta imagem tem dois momentos: há o interesse explícito de fundir a significação com a particularidade: a fala encontra seu sentido no contexto das condutas particulares que lhe é comum. Mas também há o interesse de chamar a atenção para a sua sedimentação. $O$ terreno próprio a esta sedimentação pode ser circunscrito desde que tenhamos compreendido que cada palavra ao mesmo tempo antecipa a abertura de um campo de conhecimento e empreende uma retomada da relação com o mundo cultural que lhe é próprio. É assim que uma opinião nova 
se cristaliza. A fala retoma e supera o sentido do mundo sensível, mas conserva e continua a expressividade muda através da cultura. A fala pressupõe a vida muda da percepção e o falante articula as significações dadas metamorfoseando-as em um movimento de expressão. Nos anos 50, o filósofo não pensa mais ser possível a ruptura do silêncio da consciência. Mas como, exatamente, o sentido da fala aparece do interior da vida muda? O excesso da linguagem é preparado no interior da particularidade, ele nasce daquilo que tem de mais individual para cair no mundo cultural como um cristal no fundo de um composto. Não há mais ruptura do silêncio como na primeira filosofia porque, agora, a fala “jamais penetra inteiramente o 'silêncio eterno' da subjetividade privada” (MERLEAU-PONTY, 1999, p.61). Notemos que se trata da vincular a subjetividade e a particularidade, a potência e o ato, com o intuito de sanar o problema da relação entre eles. $\mathrm{O}$ ato da fala não esgota mais o silêncio porque ele mesmo é dobra do silêncio: o silêncio "prossegue por baixo das palavras, não cessa de envolvê-las" (MERLEAU-PONTY, 1999, p.61). Assim, para compreender esta operação que transforma um silêncio em fala o filósofo nos dá uma dica: "precisamos fingir nunca ter falado" e operar sobre a linguagem "uma redução sem a qual ela ainda se ocultaria a nossos olhos reconduzindo-nos ao que nos significa, precisamos olhá-la como os surdos olham os que falam" (MERLEAUPONTY, 1999, p.65).

Vale observar que nos anos 50 Merleau-Ponty interpreta o silêncio como sendo de uma subjetividade. Ainda que as significações linguageiras se relacionem de modo diacrítico e o falante seja uma energia, ainda que haja circularidade e expressão entre particularidade e universalidade, resta que ainda é preciso outras categorias para tematizar a experiência da linguagem. A concepção da linguagem presente no último período pretende, finalmente, suspender o registro da subjetividade ou da consciência. A aposta na intervenção do espírito na compreensão da ultrapassagem da expressão natural pela expressão linguística equivale ao afastamento definitivo da filosofia da consciência? A ascensão da cultura sobre a natureza resolve o problema da anterioridade da consciência sobre o mundo? 
No Prefácio de Signos o filósofo nos diz que o pertencimento de todos ao mundo sensível constitui uma espécie de "fascinação" e que, enfim, "a palavra, como dizíamos, romperia essa fascinação" (MERLEAUPONTY, 1996b, p.24). É provável que ele esteja se referindo a sua própria concepção desenvolvida em 1945, pois como esclarece um pouco mais adiante, a fala não pode ser considerada como "derivada ou segunda”. No intuito de retificar esta ideia, ainda no mesmo parágrafo, o filósofo nos diz que a fala rompe esta fascinação, mas não a suprime. $\mathrm{Na}$ verdade, a fala "diferencia" esta fascinação, ela a lança para adiante: a fala "toma seu elam, ela está enrolada na onda de comunicação muda. Ela arranca ou despedaça significações no todo indiviso do nomeável, como os gestos no do sensível" (MERLEAU-PONTY, 1996b, p.24). O poder criador da linguagem não se estabelece mais por uma espécie de ruptura radical com o mundo da percepção. O logos vivo na linguagem sublima o logos do mundo sensível silencioso. Tomada em seu sentido mais amplo, a sublimação deve nos reenviar à transformação ou a passagem de um estado para outro, assim como no caso da ebulição em que a água metamorfoseia-se em ar. Se a linguagem molda os dados da percepção, resta que ela se institui sobre a abertura prévia que é a percepção. Sujeito de uma ação, o falante não possui as palavras diante dele como ideias: ele as antecipa e as estabelece em outro nível. O ser que percebe e fala é o mesmo, porém a fala traz um "fermento de transformação” (MERLEAU-PONTY, 2001b, p.252). Ainda que a percepção e a linguagem organizem seus elementos de modo diacrítico, a linguagem retoma sedimentos graças aos quais se estabelece o conhecimento, a comunicação e a criação do mundo cultural. Como compreender a diferença entre a percepção e a linguagem? "A diferença entre a percepção e a linguagem [consiste em] que vejo as coisas percebidas e que, pelo contrário, as significações são invisíveis. O ser natural está em repouso em si mesmo, o meu olhar pode deter-se nele. O ser do qual a linguagem é a casa não pode fixar, olhar, senão de longe" (MERLEAUPONTY, 2001b, p.263). ${ }^{15}$ Para explorar esta diferença é preciso abordar rapidamente a noção de corpo e de mundo na última filosofia de Merleau-Ponty. 
O corpo não é mais estudado no interior da ambiguidade existente entre o corpo objetivo e o corpo subjetivo. O filósofo se interessa por aquilo que há entre os extremos. É esta ligação indissolúvel que vem trazer a noção de carne. O corpo está no meio das coisas, é uma coisa entre coisas, mas, além disto, ele é dotado de reflexividade. Ele é visto como todas as outras coisas do mundo, mas também é vidente, ele é um visível que vê. Mais: ele se vê vendo... O corpo é um visível que se faz vidente no interior da visibilidade. O corpo tem um "estofo" comum com o mundo, ele é um ser paradoxal, ele possui "duas faces": por um lado, é "coisa entre coisas", por outro, ele é "aquilo que as toca e as vê" (MERLEAU-PONTY, 2001b, p.133). Desde então, o corpo não é mais o mediador da experiência, e isto, porque ele não tem mais privilégio do que nenhum ser sensível, porém, ele é um "sensível exemplar" (MERLEAU-PONTY, 2001b, p.132). O corpo é ao mesmo tempo visível e vidente, observável e reflexivo. Ele é um sensível como outro qualquer, mas, além disto, ele é "um sensível no qual se faz uma inscrição de todos os outros, sensível pivô, ao qual participam todos os outros, sensível-chave, sensível dimensional. Meu corpo é, no mais alto grau, aquilo que qualquer coisa é: um isto dimensional. É a coisa universal" (MERLEAU-PONTY, 2001b, p.234). O que é uma dimensão? Através desta noção, particularidade e abertura não podem mais ser separadas. Aqui, não se trata mais de afirmar nem a ambiguidade nem a circularidade. A noção de dimensão exprime a ideia de uma coisa particular ou individual que já é um universal, uma abertura.

No mundo percebido as cores também possuem uma "função ontológica". O mundo se torna apto a representar todas as coisas. ${ }^{16} \mathrm{~A}$ relação entre o corpo e o mundo é relativa à sensibilidade e aos sentidos, ela é estesiológica. No mundo sensível o que está em questão também é a dimensionalidade do ser, pois as coisas já são dimensões: “cada fato pode ser uma dimensão" - "as cores, os sons, as coisas como as estrelas de Van Gogh, são focos, irradiações do ser” (MERLEAU-PONTY, 1996b, p.14). As cores são certa espécie de ser que ao mesmo tempo se impõe com determinada particularidade e como abertura. Cada parte do mundo nos dá uma presença particular, um ser próximo ou familiar, mas também certa dimensão, uma ausência. É neste contexto que a noção de carne é introduzida como uma espécie de "massa" que deve ser definida pela 
noção de reversibilidade entendida como "verdade última" (MERLEAUPONTY, 2001b, p.201). Há, então, a "carne das coisas" ou a "carne do mundo" que possui uma espessura que é o próprio meio de comunicação entre a corporeidade do vidente e a visibilidade da coisa. Quando Merleau-Ponty fala da "carne do visível", trata-se do "paradoxo do Ser". Isto significa que "o ser carnal, como ser das profundezas, de várias camadas ou de várias faces, ser de latência, e apresentação de uma ausência, é um protótipo do Ser, do qual nosso corpo, sensível que sente, é uma variante muito notável” (MERLEAU-PONTY, 2001b, p.132). ${ }^{17}$ A carne é enigmática porque possui uma "propriedade primordial", ela é dimensional: "estando aqui e agora, ela irradia por toda parte e para sempre, sendo indivíduo, é também dimensão universal" (MERLEAU-PONTY, 2001b, p.231). Em suma: a carne é ao mesmo tempo indivisão e fissão ou segregação. Ela é ao mesmo tempo "indivisão deste Ser sensível que eu sou e de todo o resto que se sente em mim" (MERLEAU-PONTY, 2001b, p.231) e divisão interior ao Ser que não o separa de si mesmo. Esse enigma descrito inicialmente no nível do corpo e do mundo sensível repercute em todos os níveis da experiência.

Para compreender o sentido da reflexão merleau-pontiana sobre a linguagem em torno dos anos 60 é preciso retomar a discussão da relação entre a linguagem e o silêncio. Não se trata mais de dizer que o silêncio seja expressão da experiência muda da consciência pré-reflexiva: ele é, sim, expressão do próprio mundo sensível mudo. A linguagem "só vive do silêncio" e "tudo o que jogamos aos outros germinou neste grande país mudo que não nos abandona” (MERLEAU-PONTY, 2001b, p.165). Como descrever o nascimento da fala? Enquanto alguém que experimenta a necessidade de falar, o próprio filósofo deve interpretar "o nascimento da fala como uma bolha do fundo da experiência muda" (MERLEAU-PONTY, 2001b, p.165). A fala, assim como a criação, é compreendida como uma espécie de operação que se alimenta na raiz do ser bruto, ela está imersa neste elemento que é relançado para o futuro de modo criativo: "trata-se de uma criação que é chamada e engendrada pelo Lebenswelt como historicidade operante, latente, que prolonga e dela dá testemunho" (MERLEAU-PONTY, 2001b, p.225). O falante apreende o mundo silencioso em sua universalidade e o fixa em obra. É o próprio mundo sensível que chama a linguagem, a qual se apoia, se 
diferencia e vai além do mundo natural. Merleau-Ponty nos diz que "a teoria da carne vai se prolongar em teoria da carne da linguagem e da carne da história” (MERLEAU-PONTY, 1958). Para nós, o que está em jogo é a ligação da carne com a palavra. A reversibilidade que define a carne se expressa na relação visível-vidente, tocante-tocado e no sistema tocar-visão. Porém, esta reversibilidade presente no mundo sensível "existe em outros campos, é mesmo incomparavelmente mais ágil, e capaz de estabelecer entre os corpos relações que desta vez, além de alargarem, irão definitivamente ultrapassar o campo do visível" (MERLEAU-PONTY, 2001b, p.187). Merleau-Ponty avança sua pesquisa e reconhece outro tipo de reversibilidade existente entre os movimentos da fonação e da audição ou entre a garganta e o ouvido: "esta nova reversibilidade e emergência da carne como expressão constituem o ponto de intersecção do falar e do pensar no mundo do silêncio" (MERLEAU-PONTY, 2001b, p.188). É neste ponto que há sublimação da carne do mundo. Estas ideias levam o filósofo a reconhecer que a "reversibilidade da fala e do que ela significa" (MERLEAUPONTY, 2001b, p.199) não nos entrega a um mundo absolutamente estendido diante de um pensamento puro. A linguagem "nunca fala absolutamente: nenhum texto, nenhuma fala, nunca é outra coisa que dobra das aparências" (MERLEAU-PONTY, 1958).

O ponto de partida do filósofo é, finalmente, um "há de inerência", um "há prévio", ou melhor, o Ser bruto. A afirmação de que "há ser" ("há mundo", "há alguma coisa") significa que ele não parte do nada, ex nihilo: "partimos de um relevo ontológico" (MERLEAU-PONTY, 2001b, p.119). Talvez, se Merleau-Ponty tivesse tido tempo de expor as modificações que ele introduz em suas ideias propósito da relação entre a significação pura e este relevo ontológico, talvez fosse possível abordar mais detalhadamente aquilo que para ele era um problema, a saber:

"mostrar que o pensamento só se compreende como realização por outros meios deste voto do HÁ, por sublimação do HÁ e realização de um invisível que é exatamente o avesso do visível, a potência do visível. De modo que entre som e sentido, a fala e o que ela quer dizer, há ainda relação de reversibilidade e nenhuma discussão de prioridade, a troca das falas sendo exatamente diferenciação da qual o pensamento é a integral" (MERLEAU-PONTY, 2001b, p.188). 
Afastada a prioridade entre som e sentido é possível reencontrar a dimensionalidade do ser também ao nível da linguagem. Segundo MerleauPonty, este é o ponto mais dificil, pois se trata de investigar "o laço da carne com a ideia, do visível e da armadura interior que ele manifesta e que ele oculta" (MERLEAU-PONTY, 2001b, p.193). O filósofo lança mão de algumas páginas de Proust em que o escritor explora o mundo invisível e desvenda um universo de ideias a partir de certas "noções sem equivalentes" que não se destacam das aparências sensíveis. Aqui, seria preciso retornar a Proust, já que ninguém teria ido mais longe do que ele na "fixação das relações do visível e do invisível, na descrição de uma ideia que não é o contrário do sensível, mas que é seu dúplice e sua profundidade" (MERLEAU-PONTY, 2001b, p.193). O tema da passagem do mundo mudo ao mundo falante, da passagem da generalidade do corpo e do mundo para a generalidade cultural é um dos temas que ficaram sem um arremate final na obra de Merleau-Ponty. Porém, há algumas indicações a respeito que devemos retomar: "É como se a visibilidade que anima o mundo sensível emigrasse, não para fora do corpo, mas para outro corpo menos pesado, mais transparente, como se mudasse de carne, abandonando a do corpo pela da linguagem, e assim se libertasse, embora sem emancipar-se inteiramente de toda condição" (MERLEAU-PONTY, 2001b, p.198). Para dar vazão a estes pensamentos é preciso, primeiramente, matizar a diferença entre o agente sensorial que é o corpo sensível e o agente ideal que é a palavra. Há a "carne maciça" do corpo sensível que não subsiste sem a "carne sutil" da palavra, "o corpo momentâneo sem um corpo glorioso" (MERLEAU-PONTY, 2001b, p.192). Em seguida, é indispensável ler a literatura como uma "linguagem conquistadora, ativa e criadora" (MERLEAU-PONTY, 2001b, p.198). Não se trata de abandonar as "ideias adquiridas, disponíveis e honorárias", elas são úteis e constituem a situação particular do todo falante. Este segundo tipo de consideração da linguagem permite o emprego dos sedimentos presentes no mundo lingüístico em uma espécie de "vida e percepção segundas" (MERLEAU-PONTY, 2001b, p.199) que reenvia a algo novo. A linguagem operante e a ideia não se distinguem mais.

Retomemos o tema do nascimento da fala. Dizer que ela surge do fundo da experiência muda não é o mesmo que dizer que há, depois do 
seu nascimento, destruição ou conservação do silêncio. A fala diferencia o silêncio e o conduz mais longe. $\mathrm{Na}$ verdade, "são as próprias coisas, do fundo de seu silêncio" que, quando falamos, querem ser conduzidas à expressão (MERLEAU-PONTY, 2001b, p.18). ${ }^{18}$ O falante emprega a linguagem para exprimir este liame pré-lógico: falamos o que o silêncio quer dizer. Em princípio, a fala retoma e prolonga o silêncio do mundo mudo, em seguida, ela o redobra. A própria linguagem é "um mundo, ela mesma um ser, - um mundo e um ser em segunda potência, já que não fala no vazio, que ela fala do ser e do mundo, e redobra então seu enigma ao invés de fazê-lo desaparecer" (MERLEAU-PONTY, 2001b, p.130).A linguagem trabalha com o silêncio porque ela mesma é silencio. A fala viva é um silêncio organizado ou concentrado que reencontra a experiência muda e exprime seu sentido: ela é a fala vertical, a fala do silêncio. O sentido da linguagem surge do interior da experiência da totalidade do mundo: por um lado, a linguagem se apoia e prolonga a produtividade ou logos do mundo natural silencioso; por outro, ela se diferencia e se institui sobre a natureza, ela se estabelece na ordem do logos do mundo cultural proferido. A reversibilidade da fonação e da audição que se encontra na linguagem permite ao falante se posicionar no mundo das significações sedimentadas, universo de significações disponíveis que é o avesso da linguagem instituinte. As cristalizações da linguagem podem e devem ser retomadas e reativadas assim como o carvão. A linguagem retoma, reativa e lança para adiante os tesouros tanto do mundo silencioso quanto aqueles soterrados no mundo cultural. A linguagem faz "brotar a significação" (MERLEAU-PONTY, 2001b, p.253). Essa significação, ou melhor, a essência verbal (Wesen) desta significação, é algo que "se esvazia interiormente de sua carne para deixar transparecer uma estrutura, uma massa trabalhada interiormente por um tipo de ebulição, um oco no Ser" (MERLEAU-PONTY, 1958). Esta estrutura ou massa de que fala o filósofo não é a "estrutura sensível" compreendida através de sua relação ao corpo ou à carne do mundo sensível. Trata-se, sim, de uma "estrutura invisível” que só pode ser explorada através de sua relação com o logos, com a fala: "o sentido invisível é a membrana da fala" (MERLEAUPONTY, 2001b, p.273). Isto só é possível porque há invasão do mundo das ideias sobre a linguagem, que, por sua vez, invade o mundo das ideias. É assim que o falante toca o intocável. A linguagem reorganiza a estrutu- 
ra sensível do mundo: sua "estrutura interna sublima a relação carnal com o mundo" (MERLEAU-PONTY, 2001b, p.258). Não estando atrás dos signos sensíveis, a significação que nasce na linguagem é o próprio movimento da cadeia verbal no interior de um campo em que há uma suscitação, para cada coisa ou signo, de um silêncio.

São muitas as repercussões desta abordagem da linguagem para aquilo que é a filosofia. No que diz respeito ao seu caráter criador ou operante, a filosofia enquanto linguagem atende ao apelo das vozes do silêncio porque ela mesma está aberta sobre o mundo silencioso. $\mathrm{O}$ falante reencontra aquilo que se articula nele sem que ele o saiba. Falando, ele segue a modulação da cadeia verbal e se pauta por uma "fala sem conceito" (MERLEAU-PONTY, 1958). A filosofia se interessa por esta mediação característica da linguagem porque há aí a possibilidade de um "vir a ser significativo pela articulação interna e sem referência a uma ordem de ideias" (MERLEAU-PONTY, 1958). A filosofia “continua [este] ensaio de articulação que é o Ser de todo ser” (MERLEAU-PONTY, 2001b, p.61).

Em sua última filosofia Merleau-Ponty formula de modo surpreendente o problema focalizado aqui: "como toda filosofia é linguagem e consiste, todavia, em reencontrar o silêncio" (MERLEAU-PONTY, 2001b, p.263)? Na verdade, é possível encontrar outras formulações do paradoxo em questão:

"O filósofo fala, mas é uma fraqueza nele, e uma fraqueza inexplicável:

ele deveria se calar, coincidir em silêncio, e alcançar no Ser uma

filosofia já feita. Tudo se passa, ao contrário, como se ele quisesse

colocar em palavras certo silêncio nele que ele escuta. Sua 'obra' inteira é este esforço absurdo. Escrevia para dizer seu contato com o ser; não o disse nem saberia dizê-lo, pois que é silêncio. Então, ele recomeça...”

(MERLEAU-PONTY, 2001b, p.164).

Em princípio o filosofo, assim como o escritor, é alguém a quem podemos pedir conselhos e opinião, pois "não admitimos que eles mantenham o mundo em suspenso, queremos que eles tomem posição eles não podem declinar as responsabilidades do homem que fala" (MERLEAU-PONTY, 1999b, p.13-14). Aqui, o filósofo é aquele que "se desperta e que fala" (MERLEAU-PONTY, 2002, p.63); já a filosofia consiste na fala, ou melhor, em falar de maneira justa (cf. MERLEAU- 


\section{4}

PONTY, 1996b, p.433). Em seguida, é preciso reconhecer que falar é reenviar àquilo que está sob a linguagem, isto é, ao silêncio, o qual não é um vazio. Trata-se, ao contrário, de reconhecer que há no silêncio um sentido que deve ser trazido à fala, ou antes, é preciso "captar as falas surdas que o ser murmura” (MERLEAU-PONTY, 1999, p.11). Como compreender esta dupla vertente da análise? Para isto é preciso compreender que a própria filosofia deve exprimir um silêncio que sempre volta a envolver a fala. E isto, porque não há como explorar exaustivamente a linguagem, porque não há como esgotar "a própria voz das coisas, das ondas e das florestas" (MERLEAU-PONTY, 2001b, p.201). O silêncio do mundo sensível é inexaurível, e é precisamente este seu tesouro. Redobro do silêncio, a fala é envolvida pelo silêncio, que é, novamente, expresso pela fala. Aqui, a filosofia deve ser compreendida como "a reconversão do silêncio e da fala um no outro: 'é a experiência [...] ainda muda que se trata de conduzir à expressão pura de seu próprio sentido"” (MERLEAU-PONTY, 2001b, p.169). Nesse contexto, o que faz a filosofia? Ela é ao mesmo tempo interrogação do mundo da experiência e criação de uma nova linguagem. Essa dupla face do comportamento filosófico não constitui uma impossibilidade para a filosofia porque não se trata para ela de resolver um problema de conhecimento. Não se trata, enfim, de encontrar uma solução filosófica para este paradoxo. ${ }^{19}$ Merleau-Ponty inscreve a filosofia no interior de um enigma que se aprofunda na medida em que se avança em sua interrogação. Por um lado, a filosofia é "aproximação do distante como distante, ela é também questão posta ao que não fala" (MERLEAU-PONTY, 2001b, p.136). Por outro, "a filosofia consiste em restituir uma potência de significar, um nascimento do sentido ou de um sentido selvagem, uma expressão da experiência pela experiência que ilumina, particularmente, o domínio da linguagem" (MERLEAU-PONTY, 2001b, p.201). A filosofia não pode ignorar o problema da fala assim como não pode correr o risco de se anular ao recusar sua tarefa de mediação. Ela deve circunscrever seu trabalho entre a descida abaixo da linguagem e das significações, e a aposta filosófica que se cristaliza naquilo que falamos e significamos. Enfim, o filósofo deve "articular em tese ou enunciado" o contato que ele realiza com o "solo profundo de 'opiniões' mudas implicadas em nossa vida". O encaminhamento merleau-pontiano desta questão consiste em um apro- 


\section{fundamento da linguagem porque a própria filosofia deve "inventar uma nova linguagem capaz de reconquistar isto mesmo que a precede. É a filosofia. Falar do que está sob a fala" (MERLEAU-PONTY, 1958).}

${ }^{1}$ Em relação à experiência perceptiva não se pode deixar de notar que ela aparece precisamente na história individual do sujeito. $\mathrm{O}$ ato da percepção se "aproveita de um trabalho já feito": dizer que percebemos com o corpo e com os sentidos significa que tanto um quanto outro devem ser interpretados como um "saber habitual do mundo", uma "ciência implícita ou sedimentada". Em relação ao objeto percebido, vale notar que temos consciência dele como "um objeto inesgotável" e que o sujeito da percepção jamais se liberta dele, pois entre o objeto e o sujeito "existe este saber latente que nosso olhar utiliza, do qual apenas presumimos que seu desenvolvimento racional seja possível". A percepção "retoma um saber que não põe em questão. Aquele que percebe [...] tem uma espessura histórica, retoma uma tradição perceptiva e é confrontado com um presente. Na percepção [...] nós somos para o objeto e confundimo-nos com esse corpo que sabe mais do que nós sobre o mundo, sobre os motivos e os meios que se têm de fazer sua síntese" (MERLEAU-PONTY, 1996, p.275).

2 Gelb, em outro artigo, nos diz que "mesmo no domínio olfativo podemos nos comportar de maneira categorial, por exemplo, classificar os odores segundo um princípio qualquer" (GELB, 1969).

${ }^{3}$ No início de sua carreira Goldstein distingue "uma linguagem automática (um 'saber verbal exterior') e uma linguagem no sentido pleno (denominação verdadeira) que ele reporta à 'atitude categorial'” (MERLEAU-PONTY, 1968, p.37). Aqui, trata-se de reconhecer uma dupla função da linguagem: a concreta que "responde a situações efetivas" e a abstrata que considera "a palavra em si como entidade puramente abstrata que responde a situações fictícias ou a "problemas"” (MERLEAU-PONTY, 2001, p.60). No paciente acometido de afasia a linguagem é reconduzida à sua função concreta; há uma "queda" da linguagem do nível categorial para o nível automático.

4 O mesmo texto nos diz ainda que a linguagem do adulto "mostra o rico tesouro de saber que encerra a linguagem, suas vastas possibilidade de emprego eficaz, de operações lógicas, exatas ou práticas, sua extraordinária utilidade de instrumento no interior de uma atividade determinada por uma situação concreta; mas ela revela, por outro lado, a total ausência de espontaneidade e de produtividade de uma linguagem destacada do conjunto das atividades da vida" (GOLDSTEIN, 1969).

5 “O sentido do gesto não está contido no gesto enquanto fenômeno físico ou fisiológico. O sentido da palavra não está contido na palavra enquanto som. Mas é da definição do corpo humano apropriar-se, em uma série indefinida de atos descontínuos, de núcleos significativos que ultrapassam e transfiguram seus poderes naturais. Esse ato de transcendência encontra-se primeiramente na aquisição de um comportamento, depois na comunicação muda do gesto: é pela mesma potência que o corpo se abre a uma conduta nova e faz com que testemunhos exteriores a compreendam. Aqui e ali, um sistema de poderes definidos repentinamente se 
descentra, rompe-se e reorganiza-se sob uma lei desconhecida pelo sujeito ou pelo testemunho exterior, e que se revela a eles nesse momento mesmo" (MERLEAU-PONTY, 1996, p.262).

${ }^{6}$ Lembremos que tal gesto metodológico deve fazer eco àquele gesto típico de Bergson em que o filósofo diz em Matéria e memória que irá "fingir por um instante" não saber nada sobre as discussões tradicionais sobre as relações entre a matéria e espírito, a realidade ou a idealidade do mundo exterior.

7 A esta altura do texto que estamos comentando, Merleau-Ponty chama atenção para a necessidade de um "princípio mediador" que ponha fim a dualidade entre a perspectiva subjetiva (sistema) e a perspectiva objetiva (desenvolvimento) da linguagem tal como se encontra presente em Saussure. Foram seus sucessores que reconheceram a necessidade desta mediação. Trata-se, aqui, de chamar a atenção para a noção de "esquema sublinguístico" elaborada pelo linguista Gustave Guillaume. Segundo Guillaume, existem esquemas que são interpretados como fatos pancrônicos válidos para todas as línguas do mundo. Isto significa que, por um lado, temos o conjunto do mecanismo profundo da língua (esquema sublinguístico) e, por outro, a representação dos movimentos pelo pensamento. Segundo um interprete da obra de Guillaume, esta última característica permite não só explicar os mecanismos genéticos na origem da linguagem, mas também serve para atenuar suas diferenças. Em relação à primeira característica, ela nos reenvia à realidade profunda desses esquemas que revelam, segundo a expressão de Guillaume, uma "sutil geometria ladeada no pano de fundo do espírito humano" (THAVAUD-PITON, 2002). Esta noção de esquema sublinguístico exprime uma espécie de "tema" ou de "projeto fundamental" que, segundo Merleau-Ponty, "passa despercebido quando se trabalha com as categorias do senso comum ou com as [categorias] da antiga gramática, mas cuja vida operante se manifesta quando o linguista constrói as categorias novas exigidas para a coordenação dos fatos” (MERLEAU-PONTY,1966, p.154). Este esquema cultural deve interpretado como uma "arquitetônica nos seus diferentes meios de expressão que se desenvolve através do tempo e orienta a sincronia” (MERLEAU-PONTY, 2001, p.85): ele que torna possível a comunicação e a comunidade linguística.

8 Goldstein alerta seu leitor para o fato de que a verdadeira mudança na interpretação da linguagem só se deu quando a análise da linguagem se tornou relativa ao comportamento individual em geral. Este novo modo de tratar a linguagem foi preparado por G. Herder e por W. Von Humboldt. Para o primeiro, toda linguagem tem seu ponto de partida nos sentimentos; porém, a linguagem humana como um todo é caracterizada pela reflexão: "Essa capacidade, intrínseca para o homem e separando-o de todos os animais, capacita-o para características abstratas da complexidade das impressões, para fixá-las, e reconhecê-las novamente em sua particularidade, isto é, para construir conceitos. $\mathrm{O}$ agente dessa realização é a palavra. Através desta capacidade, sons tornam-se linguagem”. Já o segundo, eleva este fator à última potência, para ele a essência da linguagem não se encontra em uma coleção de palavras: "as palavras aparecem como entidades separadas apenas na consideração abstrata”. A linguagem não é um fenômeno estático, mas um processo dinâmico (GOLDSTEIN, 1948).

9 Quando se trata de saber qual o sentido do comportamento linguístico dos pacientes acometidos de afasia é preciso dizer que ele fala todas as vezes em que pode empregar a linguagem automática, e não quando tem que usar a linguagem verdadeira em que o ato de

doispontos, Curitiba, São Carlos, vol. 9, n. 1, p.35-69, abril, 2012 
denominação guarda uma função. A palavra não é empregada por ele como "mediação de uma ideia". O paciente usa o conjunto de instrumentos linguísticos de modo impulsivo e instintivo, ele "se move em um aparelho de significações estereotipadas", "sua linguagem perdeu sua produtividade", ele "perdeu a possibilidade de considerar o objeto singular como participante de uma estrutura exemplar de certa categoria". Ele é incapaz de distinguir o essencial do acessório, ele tem uma deficiência na articulação entre a figura e o fundo, ele não se orienta mais em relação ao possível (MERLEAU-PONTY, 2001, p.453).

10 "Não piloto em seu navio: 1) o espírito sustenta toda a linguagem, a própria textura de cada palavra, portanto, não há pura mecânica como aquela do barco; 2) este espírito que carrega tudo é, todavia, carregado por seus produtos (sofre com sua deteriorização)" (MERLEAU-PONTY, 1953).

11 Neste livro de 1948, Goldstein nos diz que "seria preciso distinguir - de fato um tanto abstratamente - dois tipos de linguagem": a "linguagem concreta" e a "linguagem abstrata". A primeira "pertence ao comportamento concreto" "ela consiste em automatismos da fala, em 'instrumentalities of speech': sons, palavras, séries de palavras, sentenças, uma forma de nomear e de entender da linguagem em situações corriqueiras para a qual a linguagem concreta foi condicionada, e, finalmente, em expressões emocionais". A segunda é aquela que pertence à "atitude abstrata: volitiva, proposicional, linguagem racional". Goldstein não deixa de avançar uma definição daquilo que é a "linguagem cotidiana" [everyday language]: ela é uma "combinação de ambos os tipos da linguagem: em uma conversação, inicialmente automatismos podem ocorrer, em seguida o aparecimento das palavras pode ser determinado por uma atitude abstrata" (GOLDSTEIN, 1948).

12 “A 'innere Sprachform' é uma paisagem mental comum a todos os membros de uma comunidade linguística e através da qual é possível a coexistência de uns com os outros através de um meio cultural" (MERLEAU-PONTY, 2001, p.76).

13 “Tomada na sua verdadeira essência, a fala é sempre e em cada instante qualquer coisa de passageiro. Mesmo a fixação por intermédio da escrita nunca passa de uma conversação imperfeita, mumificada, que constantemente exige que seja tornado sensível o enunciado que nela habita. Em si mesma, a língua não é um produto [uma obra feita] (Ergon), mas sim uma atividade (Energueia). Daí que a sua verdadeira definição só possa ser genética. Ela é, afinal, o trabatho constantemente repetido do espírito para tornar o som articulado capaz de servir de expressão ao pensamento. Tomada em sentido estrito e imediato, trata-se da definição do ato de falar; mas, em um sentido verdadeiro e essencial, só podemos considerar como fala a totalidade deste falar" (HUMBOLDT, 1986).

14 "Se admitimos que o próprio do gesto humano é significar para além da sua simples existência de fato, de inaugurar um sentido, resulta daí que todo gesto é comparável a todos os outros, que eles revelam todos uma mesma sintaxe, que cada um deles é um começo, comporta uma sequência ou recomeço enquanto ele não é, como o acontecimento, opaco e fechado sobre ele mesmo, e uma vez por todas acabado, que ele vale para além de sua simples presença de fato, e que nisso ele é de antemão aliado ou cúmplice de todas as outras tentativas de expressão” (MERLEAU-PONTY, 1999, p.12).

15 "A linguagem = aparelho que engendra para nós percepções do invisível - As percepções do visível são já percepções do invisível: a cor torna-se invisível quando ela passa para um

doispontos, Curitiba, São Carlos, vol. 9, n. 1, p.35-69, abril, 2012 


\section{8}

nível - O espírito, o conceito, o espiritual, não são senão esta estrutura remanejada, reconstruída pela linguagem" (MERLEAU-PONTY, 1958).

16 “O 'Mundo' é este conjunto onde cada 'parte' quando a tomamos por ela mesma abre repentinamente dimensões ilimitadas - torna-se parte total”' (MERLEAU-PONTY, 2001b, p.267).

17 Não há nome na filosofia tradicional para este ser carnal. Para designá-la o filósofo emprega “o velho termo 'elemento', no sentido em que é empregado para falar da água, do ar, da terra e do fogo, isto é, no sentido de uma coisa geral” (MERLEAU-PONTY, 2001b, p.136).

18 Estas ideias que não são o contrário do mundo sensível nós não a possuímos, são elas que nos possuem. Em um inédito o filósofo elabora esta ideia em forma de sentença: "a tomada de posse do homem pela linguagem no sentido de Heidegger” (MERLEAU-PONTY, 1958). Ainda em outro lugar ele nos diz que "a linguagem nos tem mais do que nós temos a linguagem. Que é o ser que fala em nós e não nós que falamos o ser” (MERLEAU-PONTY, 2001b, p.244). O sentido do uso merleau-pontiano deste pensamento de Heidegger está em que esta fala ou linguagem que possui o homem opera um descentramento que afasta filosofia da consciência. A linguagem não é um objeto constituído pela consciência. Ressaltemos, enfim, o jogo entre passividade e atividade, o recruzamento entre eles, o qual é necessário à gênese e à vida do sentido, assim como à emergência da idealidade. Na essência verbal da fala passividade e atividade se compenetram e encontram-se, por assim dizer, um no outro. É verdade que é a fala que nos tem, ela fala em nós, porém, é preciso deixá-la falar.

19 “"A filosofia] pergunta à nossa experiência do mundo o que é o mundo antes que seja coisa de que se fala e evidentemente antes que seja reduzido a um conjunto de significações manejáveis e disponíveis: levanta essa questão à nossa vida muda, endereça-se a essa mistura do mundo e de nós que precede a reflexão, porque o exame das significações em si mesmas nos daria o mundo reduzido às nossas idealizações e à nossa sintaxe. No entanto, o que a filosofia encontra regressando às fontes, ela o diz" (MERLEAU-PONTY, 2001b, p.136).

\section{Referências bibliográficas}

GELB, A. 1969. Remarques générales sur l'utilisation des donnés pathologiques pour la psychologie et la philosophie du langage. In: CASSIRER, E. Essais sur le langage. Paris: Les Éditions de Minuit.

GOLDSTEIN, K. 1948. Langage and langage disturbance. Aphasic symptom complexes and their significance for medicine and theory of langage. Nova York: Grune \& Stratton.

1969. L'analyse de l'aphasie et l'étude de l'essence du langage. In: CASSIRER, E. Paris: Les Éditions de Minuit.

HUMBOLDT, W. 1986. Sobre a diversidade da estruturação das línguas humanas e suas influências sobre o desenvolvimento espiritual do gênero 
humano. [livro com a designação vulgar de Introdução à obra sobre o Kawi] In: JUSTO, J. Ergon ou energueia. Filosofia da linguagem na Alemanha (Sec.s XVIII e XIX). Lisboa: Apaginastantas.

MERLEAU-PONTY, M. 1966. Sens et non-sens. Paris: Nagel. 1968. Résumés de cours. Collège de France 1952-1960. Paris: Gallimard. 1996. Fenomenologia da percepção. São Paulo: Martins Fontes. 1996b. Signes. Paris: Gallimard. 1999. Prose du monde. Paris: Gallimard. 1999b. L'Oeil et l'esprit. Paris : Gallimard. 2000. Parcours deux 1951-1961. Lagrasse:Verdier. 2001. Psychologie et pédagogie de l'enfant: cours de Sorbonne 1949-1952. Lagrasse:Verdier. 2001b. Le visible et l'invisible. Paris: Gallimard. 2002. Éloge de la philosophie et autres essais. Paris: Gallimard. 1953. Notes inédites. Volume XII. 1958. Notes inédites. Volume VIII.

THAVAUD-PITON, S. 2002. Sémantique lexicale et psychomécanique guillaumienne. Paris. 492p., Doutorado em linguística, Universidade de Paris IV. 